\title{
MUTU MIKROBIOLOGIS DRUPA BUAH MERAH (Pandanus conoideus Lamk.) PADA BERBAGAI JENIS KEMASAN SELAMA PENYIMPANAN
}

\author{
Mathelda Kurniaty Roreng, Zita Letviany Sarungallo, Murtiningrum, \\ Budi Santoso, Rossa M.M. Latumahina \\ Jurusan Teknologi Pertanian, Fakultas Teknologi Pertanian, Universitas Papua, \\ Korespondensi : Jl. Gunung Salju Amban Manokwari-98314 Papua Barat,Email: \\ mathelda.roreng@gmail.com
}

\begin{abstract}
Microbiological quality is one crucial factor relating to food products quality. This quality can be measured based on the growth level of bacteria and fungi during storage of food product. The objective of this study is to determine the effect of plastic packaging types and different storage conditions on total bacteria and total fungi in fresh red fruit. The experiment was conducted using three treatments of plastic packaging, that is high-density polyethylene (HDPE), low density polyethylene (LDPE) and polypropylene (PP). Additionally, three storage conditions were applied, that is room temperature $\left(27{ }^{\circ} \mathrm{C}\right)$, cold temperature $\left(10{ }^{\circ} \mathrm{C}\right)$ and freezing temperatures $\left(-18^{\circ} \mathrm{C}\right)$. The results showed that during storage, freezing conditions inhibited the growth of bacteria and fungi. Meanwhile, the type of plastic packaging did not inhibit the growth of bacteria and fungi.
\end{abstract}

\section{Keywords : red fruit, plastic packaging, storage, total bacteria, total fungi}

\section{PENDAHULUAN}

Sebagai salah satu buah lokal Papua, buah merah sangat berpotensi dijadikan sebagai pangan fungsional karena mengandung senyawa bioaktif yaitu betakaroten dan tokoferol yang bermanfaat bagi kesehatan. Beberapa penelitian mengenai khasiat ekstrak buah merah telah dilaporkan, antara lain ekstrak buah merah secara in vitro dapat menekan proliferasi sel kanker paru A549 dan secara in vivo dapat menekan proliferasi sel LLC (Lewis lung cancer), Sarcoma180 dan A549 pada tikus (Nishigaki et al. 2010). Ekstrak buah merah juga memiliki aktivitas antiproliferasi terhadap sel kanker lainnya yaitu sel HeLa dan K-562 secara in vitro (Selly 2008), serta meningkatkan proliferasi sel limfosit mencit baik secara in vitro maupun in vivo (Susanti 2006).

Pengembangan buah merah sebagai pangan fungsional membutuhkan bahan baku yang bermutu tinggi dan aman untuk dikonsumsi, terutama dari aspek mikrobiologi.
Umumnya produk tanaman pangan merupakan media yang baik bagi pertumbuhan mikroba karena tersedianya nutrisi dan kesesuaian kondisi $\mathrm{pH}$, suhu, dan kadar air bahan pangan dengan karakteristik pertumbuhan mikroba. Adanya cemaran mikroba yang tinggi selain mempersingkat umur simpan bahan pangan juga dapat mengganggu dan membahayakan kesehatan manusia. Kelompok mikroba pembusuk akan mengubah makanan segar menjadi busuk dan menghasilkan toksin (racun), yang terkadang tidak menunjukkan adanya perubahan atau kerusakan fisik (bau busuk kurang nyata) (Djaafar \& Rahayu 2007).

Perkembangan morfologi buah dari buah merah dibagi dalam empat tahap, yaitu buah muda, agak matang, matang dan lewat matang Pemanenan buah dilakukan pada tahap buah telah matang agar diperoleh kualitas buah yang maksimal dengan kriteria bulir buah telah berisi penuh (bernas), daun seludang terbuka dan sekitar 50\% telah kering, posisi buah pada pohon dengan kemiringan $180^{\circ}$ (Santoso et al. 
2011). Setelah dipanen, buah merah segar tidak dapat disimpan lebih dari 2 hari pada suhu ruang, karena dapat ditumbuhi oleh mikroba terutama jenis kapang (Murtiningrum et al. 2011)

Salah satu upaya yang dilakukan untuk menghambat pertumbuhan mikroba pada bahan pangan adalah dengan melakukan pendinginan atau kombinasi antara pendinginan dan pengemasan. Banyak penelitian yang telah melaporkan pentingnya perlakuan suhu penyimpanan terhadap kualitas dan umur simpan buah setelah pemanenan (Dixon et al. 2004; Marcilla et al. 2006; Biolatto et al. 2005; Tembo et al. 2008, Widayat et al. 2003).

Penyimpanan buah segar dapat juga dilakukan menggunakan bahan kemasan plastik. Saat ini tersedia berbagai jenis polimer plastik yang dapat digunakan untuk pengemasan buah segar, yang mana penggunaannya dapat dioptimasi untuk setiap komoditi bahan pangan (Barry-Ryan et al. 2000).

Pada penelitian sebelumnya, penggunaan kemasan pada buah merah yang mendapat perlakuan pengeringan setelah pascapanen, mampu mengurangi kontaminasi hingga $70 \%$ dan menekan infeksi cendawan hingga 40\% (Lisangan 2009). Namun, hingga saat ini penggunaan kemasan plastik selama penyimpanan drupa buah merah segar belum pernah dilaporkan. Penelitian ini bertujuan untuk menguji pengaruh jenis kemasan plastik dan kondisi penyimpanan terhadap pertumbuhan bakteri dan kapang pada buah merah selama penyimpanan.

\section{METODE}

Bahan: Buah merah kultivars Edewewits yang berasal dari Kebun Percobaan UNIPA Kabupaten Manokwari, media Plate Count Agar (PCA), media Potato Dextrosa Agar (PDA), kloramfenikol, plastik HDPE (high density polyethylene), plastik LDPE (low density polyethylene), dan plastik $\mathrm{PP}$ (polypropylene).

Alat: Cawan petri, tabung reaksi, labu erlenmeyer, gelas ukur, autoklav, inkubator, refrigerator, freezer, dan colony counter.

\section{Prosedur Penelitian}

\section{Persiapan sampel}

Sampel buah merah dipipil kemudian hasil pipilan (drupa) tersebut dimasukkan ke dalam kemasan plastik jenis HDPE, LDPE dan PP. Setiap jenis plastik kemasan terdiri atas tiga plastik yang masingmasing diisi sampel sebanyak $200 \mathrm{~g}$. Selanjutnya masing-masing jenis kemasan tersebut disimpan pada suhu ruang $\left(27^{\circ} \mathrm{C}\right)$, suhu dingin $\left(10^{\circ} \mathrm{C}\right)$, dan suhu beku $\left(-18{ }^{\circ} \mathrm{C}\right)$. Pengujian mikrobiologi terhadap total mikroba dan total kapang pada suhu ruang dilakukan pada hari ke 0, 2,dan 4. Sedangkan pada suhu dingin dan suhu beku, masingmasing pengujian dilakukan pada hari ke 0,4 ,8,12 dan pada hari ke $0,8,16$, dan 32. Seluruh pengujian dilakukan dengan menggunan dua kali ulangan.

\section{Pengujian Total Bakteri}

Pengujian total bakteri dilakukan dengan metode uji angka lempeng total. Pengenceran sampel dilakukan dengan melarutkan $1 \mathrm{~g}$ sampel yang akan diperiksa dalam $9 \mathrm{ml}$ larutan pengencer yaitu berupa larutan fisiologis steril $(\mathrm{NaCl} \quad 0,85 \%)$. Selanjutnya larutan tersebut dibuat seri pengenceran hingga $10^{-6}$. Sebanyak $1 \mathrm{ml}$ suspensi hasil pengenceran sampel dituang ke dalam cawan petri. Ke dalam setiap cawan petri tersebut dituangkan $15 \mathrm{ml}$ media PCA steril yang telah dicairkan dengan temperatur media berkisar pada $40{ }^{\circ} \mathrm{C}$. Cawan petri selanjutnya diinkubasi pada temperatur 35-37 ${ }^{\circ} \mathrm{C}$ selama 24-48 jam dalam posisi terbalik. Setelah inkubasi, jumlah koloni yang tumbuh pada cawan dihitung berdasarkan metode bacteriological analytical manual (BAM), yaitu :

$$
\mathrm{N}=\frac{\Sigma \mathrm{N}}{\left[\left(1 \mathrm{xn}_{1}\right)+\left(0,1 \mathrm{xn}_{2}\right)+\ldots\right] \times \mathrm{D}}
$$

Dimana :

$\mathrm{N} \quad=$ jumlah koloni per $\mathrm{ml} / \mathrm{g}$ produk

$\Sigma \mathrm{N} \quad=$ jumlah seluruh koloni yang dihitung

$\mathrm{n}_{1} \quad=$ jumlah cawan pada pengenceran pertama

$\mathrm{n}_{2} \quad=$ jumlah cawan pada pengenceran kedua

$\mathrm{D} \quad=$ pengenceran pertama yang dihitung 


\section{Pengujian Total Kapang}

Pengujian total kapang dari sampel drupa buah merah dengan metode uji angka kapang total. Pengenceran sampel dilakukan dengan melarutkan $1 \mathrm{~g}$ sampel yang akan diperiksa dalam $9 \mathrm{ml}$ larutan pengencer yaitu berupa larutan fisiologis steril ( $\mathrm{NaCl} 0,85 \%)$. Selanjutnya larutan tersebut dibuat seri pengenceran hingga $10^{-4}$. Sebanyak $1 \mathrm{ml}$ suspensi hasil pengenceran sampel dituang ke dalam cawan petri. Ke dalam setiap cawan petri tersebut dituangkan $15 \mathrm{ml}$ media PDA steril yang telah ditambahkan kloramfenikol sebesar $1 \mathrm{ml} / \mathrm{L}$ dengan temperatur media berkisar pada $40{ }^{\circ} \mathrm{C}$. Cawan petri selanjutnya diinkubasi terbalik pada temperatur $20-25{ }^{\circ} \mathrm{C}$ koloni yang tumbuh pada cawan dihitung berdasarkan metode bacteriological analytical manual (BAM), yaitu :

$$
\mathrm{N}=\frac{\Sigma \mathrm{N}}{\left[\left(1 \mathrm{xn}_{1}\right)+\left(0,1 \mathrm{xn}_{2}\right)+\ldots\right] \times \mathrm{D}}
$$

Dimana :

$\mathrm{N} \quad=$ jumlah koloni per $\mathrm{ml} / \mathrm{g}$ produk

$\Sigma \mathrm{N} \quad=$ jumlah seluruh koloni yang dihitung

$\mathrm{n}_{1} \quad=$ jumlah cawan pada pengenceran pertama selama 3-5 hari. Setelah inkubasi, jumlah

$$
\begin{array}{ll}
\mathrm{n}_{2} & =\text { jumlah cawan pada pengenceran } \\
\text { kedua } & \\
\mathrm{D} & =\text { pengenceran pertama yang dihitung }
\end{array}
$$

\section{Analisis Hasil}

Hasil penghitungan total mikroba dan total kapang dibahas secara deskriptif.

\section{HASIL DAN PEMBAHASAN}

\section{Penyimpanan Suhu Ruang}

Hasil pengamatan terhadap pertumbuhan bakteri pada suhu kamar menunjukkan bahwa jumlah bakteri pada ketiga perlakuan pengemasan drupa buah merah meningkat hingga akhir pengamatan (Gambar 1). Pengamatan hari ke-2 menunjukkan bahwa pada perlakuan kemasan plastik HDPE terjadi sedikit peningkatan total bakteri dari jumlah bakteri awal sebesar 7,09 $\log$ koloni/g menjadi 7,60 log koloni/g. Sebaliknya pada perlakuan kemasan plastik LDPE menunjukkan peningkatan jumlah bakteri sekitar $1 \log$ koloni/g, menjadi 8,71 $\log \mathrm{koloni} / \mathrm{g}$ dan pada perlakuan kemasan plastik PP menunjukkan peningkatan jumlah bakteri sekitar 2 log koloni/g dengan jumlah total bakteri sebesar 9,22 log koloni/g.

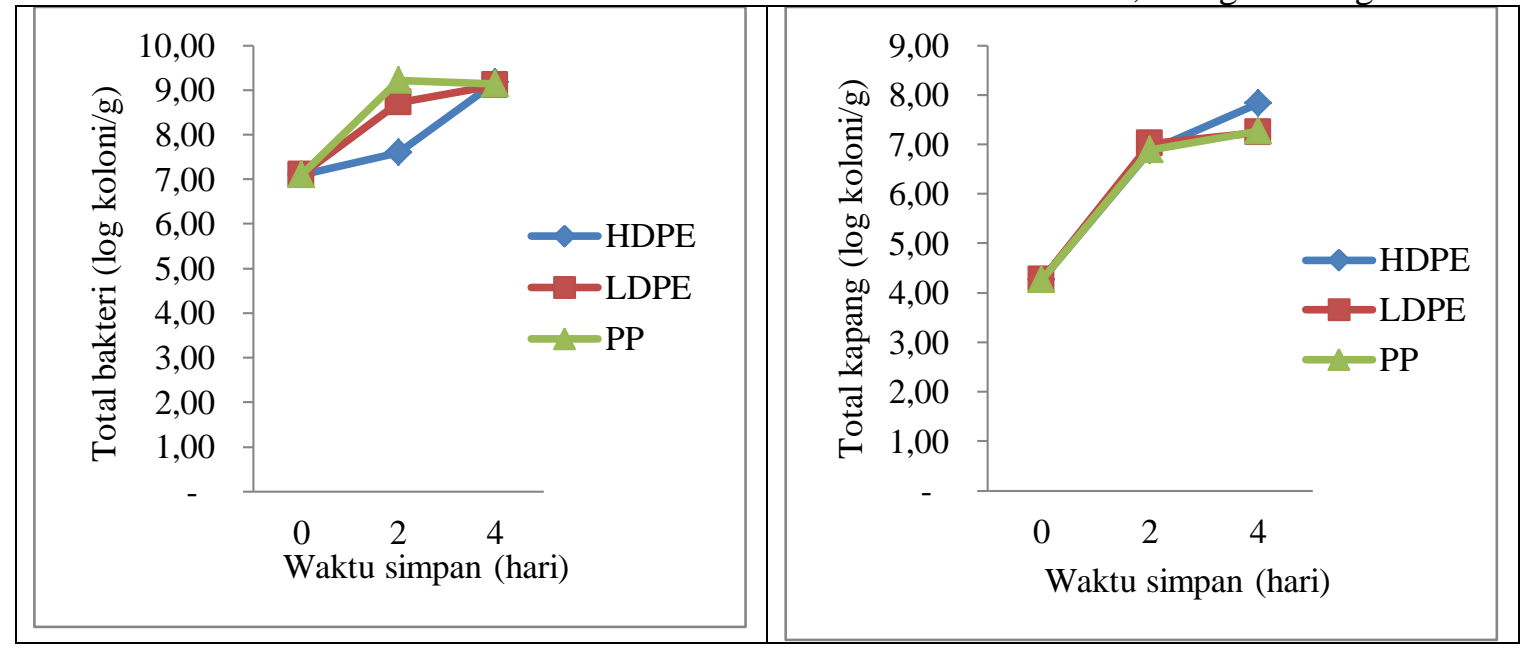

Gambar 1. Total Bakteri dan Kapang pada Penyimpanan Suhu Kamar 

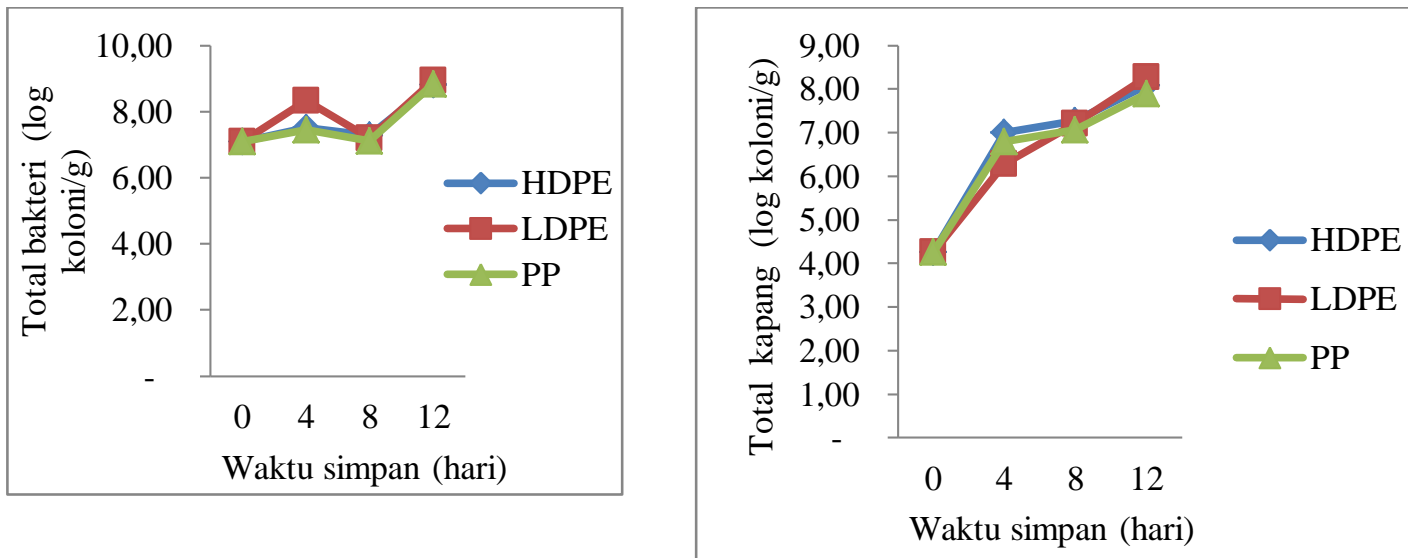

Gambar 2. Total Bakteri dan Kapang pada Penyimpanan Suhu Dingin

Pada akhir pengamatan (hari ke-4), semua perlakuan menunjukkan jumlah bakteri yang tidak berbeda jauh yaitu sekitar $9 \log$ koloni/g. Jumlah bakteri tertinggi terdapat pada kemasan plastik HDPE mencapai 9,17 $\log \mathrm{koloni} / \mathrm{g}$, sedangkan yang terendah pada kemasan plastik LDPE yaitu 9,11 log koloni/g. Pada perlakuan kemasan PP diperoleh jumlah bakteri sebesar 9,14 log koloni/g (Gambar 1). Tingginya jumlah bakteri pada hari ke-4 ini menunjukkan bahwa sampel buah merah tidak dapat disimpan pada suhu kamar selama 4 hari karena telah mengalami kerusakan mikrobiologis.

Pengamatan terhadap pertumbuhan kapang pada penyimpanan segar buah merah suhu kamar menunjukkan bahwa pada penyimpanan selama 4 hari juga telah terjadi peningkatan pertumbuhan kapang. Jumlah kapang tertinggi yaitu pada perlakuan kemasan plastik HDPE sebesar 7,9 log koloni/g, sedangkan jumlah kapang terendah pada perlakuan plastik LDPE sebesar 7,4 log koloni/g. Pada perlakuan kemasan plastik PP diperoleh jumlah kapang sebesar 7,3 log koloni/. Hasil ini menunjukkan bahwa terjadi kenaikan jumlah kapang sebesar $3 \quad$ log koloni/g dari jumlah status awal yaitu sebesar 4,26 log koloni/g. Menurut Lisangan (2009), jenis-jenis kapang yang menginfeksi buah merah segar dari lapangan adalah Aspergillus sp, Rhizopus sp, Penicillium spp. dan Fusarium sp.

Singkatnya umur simpan buah merah segar yang disimpan pada suhu kamar $\left( \pm 30{ }^{\circ} \mathrm{C}\right)$ disebabkan karena tingkat respirasi buah merah berjalan normal. Pengaruh dari aktivitas respirasi tersebut adalah terbentuknya panas sehingga akan memacu proses transpirasi buah merah, selanjutnya menyebabkan buah dapat menjadi lembab dan memicu tumbuhnya mikroba. Suhu merupakan salah satu faktor penting dalam proses terjadinya kerusakan bahan pangan. Hal ini karena suhu dapat mempengaruhi kelayuan dan laju kehilangan air, laju respirasi dan kecepatan reaksi biokimia serta laju pertumbuhan mikroba (Semangun 1996).

\section{Penyimpanan Suhu Dingin}

Penyimpanan sampel buah merah pada suhu rendah menunjukkan bahwa baik perlakuan kemasan HDPE, LDPE maupun PP menunjukkan peningkatan jumlah bakteri sekitar 1 log koloni/g hingga akhir pengamatan pada hari ke-12 (Gambar 2). Jumlah bakteri pada awal penyimpanan sebesar 7,09 log koloni/g. Pada akhir penyimpanan diperoleh jumlah bakteri tertinggi pada perlakuan kemasan plastik LDPE (8,94 log koloni/g) sedangkan jumlah bakteri terendah pada perlakuan kemasan plastik HDPE $(8,81$ log koloni/g). Perlakuan dengan kemasan plastik PP menunjukkan bahwa jumlah bakteri pada akhir penyimpanan sebesar 8,84 log koloni/g.

Penyimpanan pada suhu dingin selama 12 hari menunjukkan telah terjadi peningkatan pertumbuhan kapang sekitar 3-4 log koloni/g dari jumlah kapang awal sebesar 4,26 log koloni/g. Jumlah kapang terbanyak adalah pada perlakuan kemasan plastik LDPE yaitu 8,27 log koloni/g, sedangkan jumlah 
kapang terendah terdapat pada perlakuan kemasan plastik PP yaitu 7,90 log koloni/g (Gambar 2). Untuk perlakuan kemasan plastik HDPE data jumlah kapang diperoleh sebesar $8,09 \log \mathrm{koloni} / \mathrm{g}$. Hasil ini menunjukkan bahwa penyimpanan suhu dingin ternyata tidak cukup untuk menekan pertumbuhan kapang pada pipilan buah merah baik dengan menggunakan kemasan HDPE, LDPE maupun PP.

\section{Penyimpanan Suhu Beku}

Penyimpanan buah merah pada suhu beku menunjukkan bahwa perlakuan kemasan plastik HDPE dan LDPE mampu menekan pertumbuhan bakteri. Dari status awal bakteri sebesar 7,09 log koloni/g, pada hari ke-32 diperoleh jumlah bakteri pada perlakuan kemasan plastik HDPE dan LDPE masingmasing sebesar 7,13 log koloni/g dan 7,33 koloni/g. Sedangkan perlakuan kemasan plastik PP menunjukkan jumlah bakteri paling tinggi, yaitu sebesar 8,86 koloni/g. Hasil pengamatan penyimpanan suhu beku ini menunjukkan bahwa jenis kemasan plastik berbahan polietilen mampu menekan pertumbuhan bakteri pada drupa buah merah segar.

Pengamatan terhadap pertumbuhan kapang menunjukkan bahwa suhu beku dapat menekan pertumbuhan kapang pada drupa buah merah segar yang disimpan menggunakan kemasan plastik HDPE, LDPE

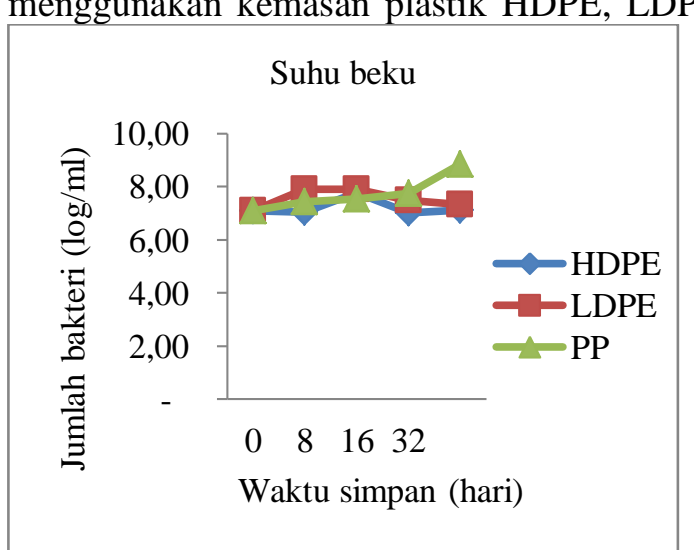

dan PP (Gambar 3). Peningkatan jumlah kapang pada suhu beku tidak melebihi $1 \log$ koloni/g dari jumlah awal sebesar 4,26 log koloni/g. Hal ini diketahui dari pengamatan jumlah kapang hari ke-32 dimana diperoleh jumlah kapang untuk perlakuan kemasan HDPE, LDPE dan PP masing masing sebesar 4,62 log koloni/g, 4,69 log koloni/g dan 4,44 $\log \mathrm{koloni} / \mathrm{g}$. Data tersebut menunjukkan bahwa tidak terdapat perbedaan nilai total kapang antara ketiga jenis kemasan plastik yang digunakan.

Kemasan yang digunakan sebagai wadah penyimpanan harus memenuhi persyaratan, yakni dapat mempertahankan mutu produk supaya tetap bersih serta mampu memberi perlindungan terhadap produk dari kotoran, pencemaran, dan kerusakan fisik, serta dapat menahan perpindahan gas dan uap air (Buckle et al. 1987). Kemasan plastik jenis polyethylene (HDPE dan LDPE) dan polypropylene dapat dibedakan atas jenis permeabilitas filmnya. Permeabilitas film terhadap gas atau uap air dari kemasan polyethylene (PE) lebih kecil daripada polypropylene (PP) (Herawati 2008). Hal ini menunjukkan bahwa gas atau uap air akan lebih mudah masuk pada bahan pengemas jenis PP daripada PE. Semakin mudah masuknya gas dan uap air tersebut akan semakin mempercepat terjadinya kerusakan mikrobiologis.

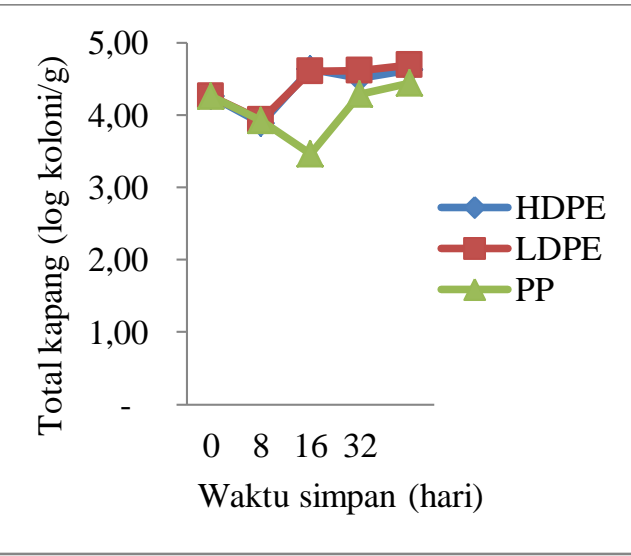

Gambar 3. Total Bakteri dan Kapang pada Penyimpanan Suhu Beku 


\begin{abstract}
Peningkatan suhu juga mempengaruhi pemuaian gas yang menyebabkan terjadinya perbedaan konstanta permeabilitas. Keberadaan air akan menimbulkan perenggangan pada pori-pori film sehingga meningkatkan permeabilitas. Permeabilitas low density polyethylene (LDPE) mencapai tiga kali permeabilitas high density polyethylene (HDPE). Menurut Butt et al. (2003), bahan pengemas dengan permeabilitas yang tinggi akan mempengaruhi kecepatan kerusakan pada bahan pangan.
\end{abstract}

\section{KESIMPULAN}

Penyimpanan pada suhu beku merupakan kondisi terbaik untuk menekan pertumbuhan bakteri dan kapang selama penyimpanan buah merah. Pada penelitian ini jenis plastik kemasan tidak memberikan pengaruh yang signifikan terhadap pertumbuhan bakteri maupun kapang selama penyimpanan.

\section{UCAPAN TERIMA KASIH}

Ucapan terima kasih kepada Direktorat Pembinaan Penelitian dan Pengabdian Kepada Masyarakat, Direktorat Jenderal Pendidikan Tinggi atas dana yang diberikan melalui Penelitian Hibah Kompetitif Penelitian Sesuai Prioritas Nasional dengan kontrak no. 546/SP2H/PP/DP2M/VII/2010 tanggal 24 Juli 2010.

\section{DAFTAR PUSTAKA}

Anonim. 1992. Prosedur Operasional Baku Pengujian Mikrobiologi. Pusat Pemeriksaan Obat dan Makanan. Direktorat Jenderal Pengawasan Obat dan Makanan Departemen Kesehatan RI, 14-15, 21-25.

BAM.www.fda.gov/Food/ScienceResearch/La boratoryMethods/BacteriologicalAnalyt icalManualBAM/ucmo63346.htm.

Barry-Ryan C., Pacussi JM., O'Beirne D. 2000. Quality of Shredded Carrots as Affected by Packaging Film and Storage Temperature. Journal of Food Science 65:726-730.
Biolatto A., Vazquez D.E., Sancho A.M., Carduza F.J., Pensel, N.A. 2005. Effect of Commercial Conditioning and Cold Quarantine Storage Treatments on Fruit of 'Rouge La Toma' Grapefruit (Citrus paradise Macf.). Postharvest Biol Technol 35:167-176.

Bucle K.A., R.A. Edwards, G.H. Fleet, dan M.Woofon. 1987. Ilmu Pangan. Jakarta: UI Press.

Butt M.S., Nasir M., Akhtar S., Sharifik. 2004. Effect of Moisture and Packaging on the Shelf Life of Wheat Flour. Int. J. Food Safety 4:1-4.

Dixon J., Smith D.B., Elmsly T.A. 2004. Fruit Age, Storage Temperature and Maturity Effects on Hass Avocado Fruit Quality and Ripening. New Zealand Avocado Growers Association Annual Research Report 4:47-53.

Djaafar T.F., Rahayu S. 2007. Cemaran Mikroba Pada Produk Pertanian, Penyakit yang Ditimbulkan dan Pencegahannya. Jurnal Litbang Pertanian 26(2):67-75.

Herawati H. 2008. Penentuan Umur Simpan pada Produk Pangan. Jurnal Litbang Pertanian 27(4): 124-130.

Lisangan MM. 2009. Pengeringan dan Pengemasan Untuk Memperpanjang Umur Simpan Buah Merah (Pandanus conoideus Lamk.). Agrotek 1(4):30-37.

Marcilla A., Zarzo M., Delrio M.A. 2006. Effect of Storage Temperature on The Flavour of Citrus Fruit. Spanish Journal of Agricultural Research 4(4):336-344.

Murtingrum, Sarungallo ZL., Santoso B. 2011. Kajian Teknologi Pascapanen Buah Merah untuk Meningkatkan Kualitas Produk Minyak Buah Merah sebagai Sumber Antioksidan Alami. [Laporan Akhir Hibah Kompetitif Penelitian Sesuai Prioritas Nasional Tahun II yang tidak dipublikasi, Universitas Negeri Papua, Manokwari].

Nishigaki T., Hirose K., Waspodo I., Shigematsu H. 2010. Antitumor Effects of Pandanus conoideus in in vitro and in vivo Studies. [Laporan Penelitian yang tidak dipublikasi, Balai Besar Industri Agro, Bogor]. 
Santoso B., Murtingrum, Sarungallo ZL. 2011. Morfologi Buah Selama Tahap Perkembangan Buah Merah (Pandanus conoideus). Agrotek 2(6):23-29.

Selly AJ. 2008. Karakterisasi Sifat FisikoKimia dan Pengujian Antiproliferasi Ekstrak Buah Merah (Pandanus conoideus Lam) terhadap Sel Kanker HeLa dan K-562 secara in vitro. [Skripsi yang tidak dipublikasi, Institut Pertanian Bogor, Bogor].

Semangun H. 1996. Pengantar Ilmu Penyakit Tumbuhan. Yogyakarta: Gadjah Mada University Press.

Susanti. 2006. Karakterisasi Ekstrak Buah Merah (Pandanus conoideus Lam.) dan Uji Biologis terhadap Proliferasi Sel Limfosit Mencit. [Skripsi yang tidak dipublikasi, Institut Pertanian Bogor, Bogor].

Tembo L., Chiteka Z.A., Kadzere I., Akinnifesi F., Tagwira F. 2008. Storage Temperature Affects Fruit Quality Attributes of Ber (Ziziphus mauritiana Lamk.) in Zimbabwe. African Journal of Biotechnology 7(8):3092-3099.

Widayat HP., Schreiner M., Huyskens S., Ludders P. 2003. Effect of Ripening Stage and Storage Temperature on Postharvest Quality of Pepino (Solanum muricatum Ait.). Food, Agriculture \& Environment 1(1):35- 41. 